\title{
PENGARUH DANA PIHAK KETIGA, NON PERFORMING LOAN, LOAN TO DEPOSIT RATIO DAN SUKU BUNGA KREDIT TERHADAP PENAWARAN KREDIT PADA BANK UMUM STUDI KASUS PADA PT. BANK RIAU KEPRI CABANG SELATPANJANG TAHUN 2007-2012)
}

\author{
Dian Pratiwi ${ }^{1}$ \& Norita ${ }^{2}$ \\ e-mail: dianpratiwi28@hotmail.com
}

\begin{abstract}
ABSTRAK
Bank merupakan badan usaha yang menghimpun dana dari masyarakat dalam bentuk simpanan dan menyalurkannya kepada masyarakat dalam bentuk kredit dan atau bentukbentuk lainnya dalam rangka meningkatkan taraf hidup masyarakat banyak. fungsi kredit yang diberikan oleh pihak bank merupakan jembatan untuk meningkatkan pendapatan nasional. Tujuan penelitian ini adalah untuk mengetahui bagaimana pengaruh Dana Pihak Ketiga, Non Performing Loan, Loan to Deposit Ratio dan Suku Bunga Kredit terhadap banyaknya Penawaran Kredit pada PT. Bank Riau Kepri Cabang Selatpanjang.

Jenis penelitian yang digunakan adalah metode deskriptif verifikatif dengan tipe analisis regresi linier berganda. Jenis data yang digunakan dalam penelitian ini adalah data kuantitatif yaitu laporan keuangan tahun 2007-2012. Hasil penelitian menunjukkan bahwa variabel dana pihak ketiga, loan to deposit ratio dan suku bunga kredit terbukti berpengaruh signifikan secara simultan terhadap penawaran kredit oleh bank. Variabel non performing loan tidak dimasukkan ke dalam model karena terbukti berkorelasi kuat dengan variabel loan to deposit ratio sehingga terjadi multikolinearitas dalam uji asumsi klasik.
\end{abstract}

Kata kunci : Dana Pihak Ketiga, Non Performing Loan, Loan to Deposit Ratio, Suku Bunga Kredit, Penawaran Kredit.

\section{PENDAHULUAN}

Pertumbuhan ekonomi merupakan salah satu masalah makroekonomi yang akan selalu dihadapi suatu negara. Sukirno (2006: 9), mendefinisikan pertumbuhan ekonomi sebagai perkembangan kegiatan dalam perekonomian yang menyebabkan barang dan jasa yang diproduksi dalam masyarakat bertambah. Sementara itu Riggs (2008) mengatakan ada beberapa cara untuk mengukur pertumbuhan ekonomi. Hal yang paling umum dilakukan untuk mengukur pertumbuhan ekonomi adalah dengan menghitung total nilai barang dan jasa yang diproduksi dalam suatu negara. Nilai tersebut biasa dikenal sebagai Produk Domestik Bruto (PDB). Selanjutnya Riggs (2008) mengemukakan bahwa tingkat pertumbuhan ekonomi dipengaruhi oleh beberapa faktor. Di antaranya adalah sumber daya alam, sumber daya manusia, modal dan teknologi. Faktor pertama adalah sumber daya alam yang tersedia untuk diolah menjadi

Universitas Telkom

Dosen Tetap Program Studi MM Universitas Telkom 
produk. Faktor ini yang memainkan peranan penting dalam efisiensi dan produktifitas ekonomi. Faktor lainnya adalah sumber daya manusia yang ditekankan pada kualitas tenaga kerja meliputi

JURNAL

MANAJEMEN INDONESIA

Vol. 12 - No. 4 April 2013 pendidikan dan keahlian yang dimiliki oleh sumber daya manusia tersebut. Selanjutnya ada faktor modal yang dibutuhkan suatu negara untuk membangun fasilitas pabrik dan bisnis, faktor ini juga memainkan peranan yang sangat penting bagi pertumbuhan ekonomi. Yang terakhir adalah faktor pengadopsian teknologi dalam kegiatan perekonomian yang bisa meningkatkan potensi pertumbuhan ekonomi.

Faktor sumber daya alam, sumber daya manusia, modal dan teknologi adalah faktorfaktor yang memengaruhi potensi produksi barang dan jasa di suatu negara. Faktor-faktor tersebut dapat mengalami peningkatan maupun penambahan baik dalam kuantitas maupun kualitasnya. Khususnya sumber daya manusia yang dapat meningkat pesat seiring dengan penambahan jumlah kelahiran, pendidikan serta pengalaman kerja. Begitu juga dalam hal perkembangan teknologi yang sedemikian cepat berkembang. Sementara investasi akan menambah jumlah barang modal. Permasalahannya adalah perkembangan kemampuan memproduksi barang dan jasa sebagai akibat pertambahan faktor-faktor produksi pada umumnya tidak selalu diikuti oleh penambahan produksi barang dan jasa yang sama besarnya. Kerap kali penambahan potensi memproduksi lebih besar dari penambahan produksi yang sebenarnya.

Untuk mengimbangi penambahan potensi memproduksi dan penambahan produksi yang sebenarnya maka dibentuklah kebijakan-kebijakan makroekonomi. Kebijakan makroekonomi yang dilakukan antara lain kebijakan dari segi penawaran yang berusaha meningkatkan efisiensi kegiatan perusahaan dan tenaga kerja melalui penciptaan suasana yang kondusif bagi perkembangan usaha.

Efisiensi penggunaan tenaga kerja dan perkembangan usaha bisa dimulai dengan memberdayakan masyarakat dalam kegiatan kewirausahaan baik di skala mikro, kecil maupun menengah. Mengenai kegiatan kewirausahaan di skala mikro dan kecil, Sriram dan Mersha (2010) mengatakan bahwa "Entrepreneurship is lauded as an engine of economic development and job creation, and Small Medium Enterprises (SMEs) often create most of new jobs in the economy." Selain itu, Tambunan (2012:2) mengatakan bahwa karakteristik Usaha Mikro Kecil dan Menengah (UMKM) sangat padat karya, sehingga mempunyai potensi pertumbuhan kesempatan kerja yang sangat besar. Pertumbuhan UMKM dapat dimasukkan sebagai elemen penting dari kebijakan nasional untuk meningkatkan kesempatan kerja dan menciptakan pendapatan, terutama bagi masyarakat miskin. Sebagai elemen penting dari kebijakan nasional untuk meningkatkan perekonomian bagi masyarakat, Wan Lee dan W. Tai (2010) menegaskan bahwa peran pemerintah sangat penting untuk turut serta menyokong pertumbuhan kewirausahaan dalam skala mikro dan kecil.

Mitra (2007) dalam penelitiannya menawarkan satu solusi jitu yang bisa diterapkan pemerintah dalam menyokong pertumbuhan dan perkembangan kewirausahaan skala mikro maupun kecil demi terwujudnya kesejahteraan masyarakat sebagai bagian dari perkembangan ekonomi nasional secara keseluruhan, "One solution that has recently gained attention particularly in the context of developing economies is the concept of microcredit".

Kredit mikro (microcredit) adalah kredit yang diberikan kepada pengusaha mikro. Menurut Undang-Undang Perbankan Nomor 10 Tahun 1998 pengertian kredit adalah penyediaan uang atau tagihan yang dapat dipersamakan dengan itu, berdasarkan persetujuan atau kesepakatan pinjam meminjam antara bank dengan pihak lain yang mewajibkan pihak peminjam melunasi utangnya setelah jangka waktu tertentu dengan pemberian bunga.

Bank menjadi pihak pemberi pinjaman bagi pihak debitur (penerima pinjaman) tidak terlepas dari fungsi dan peranan bank yang dikemukakan oleh Rivai et.al (2013: 1) sesuai dengan Undang-Undang No. 10 Tahun 1998 yang mendefinisikan bank sebagai badan usaha yang menghimpun dana dari masyarakat dalam bentuk simpanan dan menyalurkannya kepada 
masyarakat dalam bentuk kredit dan atau bentuk-bentuk lainnya dalam rangka meningkatkan taraf hidup masyarakat banyak. Emeka (2012) mengatakan bahwa peranan bank sebagai badan usaha yang menyalurkan dana kepada masyarakat dalam bentuk kredit khususnya bagi pengembangan kewirausahaan dinilai sangat besar.

Salah satu tujuan bank memberikan kredit bagi nasabah menurut Rivai et.al (2013: 199) adalah sebagai salah satu media bagi bank dalam berkontribusi dalam pembangunan. Selain itu, Rivai et. al (2013: 201) mengatakan bahwa fungsi kredit yang diberikan oleh pihak bank merupakan jembatan untuk meningkatkan pendapatan nasional. Keberadaan bank sangat dekat dengan masyarakat. Bank mampu menjangkau lebih banyak lapisan masyarakat. Sugiarto (2004) mengatakan bahwa Bank Pembangunan Daerah (BPD) sebagai salah satu bank yang ada pada sistem perbankan nasional memiliki fungsi dan peran yang signifikan dalam konteks pembangunan ekonomi regional karena BPD mampu membuka jaringan pelayanan di daerahdaerah di mana secara ekonomis tidak mungkin dilakukan oleh bank swasta. Hal ini dapat memicu percepatan pertumbuhan ekonomi yang merata.

Selatpanjang merupakan ibukota dari Kabupaten Kepulauan Meranti atau yang biasa disebut Meranti. Meranti merupakan kabupaten hasil pemekaran dari Kabupaten Bengkalis sejak tahun 2009. Meskipun baru berdiri sekitar empat tahun yang lalu, namun perkembangan pertumbuhan perekonomian di Meranti menunjukkan hasil yang menggembirakan. Berdasarkan artikel dari www.haluankepri.com (31/01/13) dikatakan bahwa "..... peningkatan rata-rata pertumbuhan ekonomi Meranti menembus angka 8,30 persen, jauh di atas pertumbuhan rata-rata ekonomi nasional." Perekonomian Indonesia pada tahun 2012 tumbuh sebesar 6,23 persen (Berita Resmi Statistik, 2013).

Tren positif pertumbuhan ekonomi Meranti, direspon positif pihak perbankan. PT. Bank Riau Kepri, sebagai salah satu bank yang siap menjadi mitra usaha kecil dan menengah, berkomitmen untuk turut menggenjot pertumbuhan ekonomi masyarakat (www.haluankepri. com $(04 / 02 / 13))$.

Sebagaimana yang diungkapkan H Irianto, SH - Manajer PT. Bank Riau Kepri Cabang Selatpanjang Kabupaten Kepulauan Meranti-dalam artikel di www.haluankepri.com (04/02/13), "Seiring dengan komitmen dan visi misi PT. Bank Riau dalam menumbuh kembangkan usaha, Bank Riau Kepri siap memberikan berbagai kemudahan kredit pinjaman modal untuk pengusaha kecil. Diharapkan dengan kebijakan ini, akan mampu memicu percepatan tumbuhnya usahausaha kreatif yang mampu menggerakkan roda ekonomi masyarakat."

Berdasarkan data Dinas Perdagangan, Koperasi dan UKM Meranti dalam artikel di www. haluankepri.com (09/01/13), jumlah pengusaha di Meranti baru berjumlah 995 pelaku usaha. Dengan besarnya potensi sumber daya alam dan posisi letak strategis Meranti sebagai kawasan niaga, jumlah ini masih sangat minim. Kabupaten Kepulauan Meranti memiliki potensi sumber daya alam, baik sektor Migas maupun Non Migas, di sektor Migas berupa minyak bumi dan gas alam, yang terdapat di daerah kawasan pulau Padang. Di kawasan ini telah beroperasi PT Kondur Petroleum S.A di daerah Kurau desa Lukit (Kecamatan Merbau), yang mampu produksi 8,500 barel/hari. Di sektor Non Migas kabupaten Kepulauan Meranti memiliki potensi beberapa jenis perkebunan seperti sagu dengan produksi 440,309 ton/tahun (2006), kelapa: 50,594.4 ton/tahun, karet: 17,470 ton/tahun, pinang: 1,720.4 ton/tahun, kopi: 1,685.25 ton/tahun. Hingga kini potensi perkebunan hanya diperdagangkan dalam bentuk bahan baku keluar daerah Riau dan belum dimaksimalkan menjadi industri hilir, sehingga belum membawa nilai tambah yang mendampak luas bagi kesejahteraan masyarakat lokal. Sementara di sektor kelautan dan perikanan dengan hasil tangkapan: 2,206.8 ton/tahun. Selain itu masih ada potensi di bidang kehutanan, industri pariwisata, potensi tambang dan energi. Di bidang perkebunan, Kabupaten Kepulauan Meranti merupakan penghasil sagu terbesar di Indonesia dengan luas lahan 57 ribu hektar, dengan total produksi 491 ribu ton/tahun. Peluang untuk menjadi pengusaha muda 
lebih terbuka lebar. Apalagi pemerintah menyediakan alokasi modal usaha dengan berbagai pola kredit yang disalurkan lewat perbankan.

JURNAL

MANAJEMEN INDONESIA

Vol. 12 - No. 4 April 2013
Menurut Stuart dalam Rivai, et.al (2013: 1), bank adalah suatu badan yang bertujuan untuk memuaskan kebutuhan kredit, baik dengan alat-alat pembayaran sendiri, dengan uang yang diperolehnya dari orang lain, maupun dengan jalan mengedarkan alat-alat penukar uang berupa uang giral. Sedangkan menurut Perry dalam Rivai, et.al (2013; 1), bank adalah suatu badan usaha yang transaksinya berkaitan dengan uang, menerima simpanan (deposit) dari nasabah, menyediakan dana atas setiap penarikan, melakukan penagihan cek-cek atas perintah nasabah, memberikan kredit, dan atau menanamkan kelebihan tersebut sampai dibutuhkan untuk pembayaran kembali.

Menurut Undang-Undang Perbankan Nomor 10 Tahun 1998 kredit adalah penyediaan uang atau tagihan yang dapat dipersamakan dengan itu, berdasarkan persetujuan atau kesepakatan pinjam meminjam antara bank dengan pihak lain yang mewajibkan pihak peminjam melunasi utangnya setelah jangka waktu tertentu dengan pemberian bunga.

Dalam artian luas pengertian kredit dalam Kasmir (2009: 97) diartikan sebagai kepercayaan. Begitu pula dalam bahasa latin kredit berarti "credere" artinya percaya. Maksud dari percaya bagi pemberi kredit adalah kepercayaan kepada penerima kredit bahwa kredit yang disalurkannya pasti akan dikembalikan sesuai perjanjian. Sedangkan bagi penerima kredit merupakan penerimaan kepercayaan sehingga mempunyai kewajiban untuk membayar sesuai jangka waktu.

Adapun tujuan utama pemberian suatu kredit menurut Kasmir (2009: 100-101) antara lain sebagai berikut:

1) Mencari keuntungan

Yaitu bertujuan untuk memperoleh hasil dari pemberian kredit tersebut. Hasil tersebut terutama dalam bentuk bunga yang diterima oleh bank sebagai balas jasa dan biaya administrasi kredit yang dibebankan kepada nasabah.

Keuntungan ini penting untuk kelangsungan hidup bank. Jika bank yang terus-menerus menderita kerugian, maka besar kemungkinan bank tersebut akan dilikuidasi (dibubarkan).

2) Membantu usaha nasabah

Tujuan lainnya adalah untuk membantu usaha nasabah yang memerlukan dana, baik dana investasi maupun dana untuk modal kerja. Dengan dana tersebut, maka pihak debitur akan dapat mengembangkan dan memperluaskan usahanya.

3) Membantu pemerintah

Bagi pemerintah semakin banyak kredit yang disalurkan oleh pihak perbankan, maka semakin baik, mengingat semakin banyak kredit berarti adanya peningkatan pembangunan di berbagai sektor.

Keuntungan bagi pemerintah dengan menyebarnya pemberian kredit adalah sebagai berikut.

a) Penerimaan pajak, dari keuntungan yang diperoleh nasabah dan bank.

b) Membuka kesempatan kerja, dalam hal ini untuk kredit pembangunan usaha baru atau perluasan usaha akan membutuhkan tenaga kerja baru sehingga dapat menyedot tenaga kerja yang masih menganggur.

c) Meningkatkan jumlah barang dan jasa, jelas sekali bahwa sebagian besar kredit yang disalurkan akan dapat meningkatkan jumlah barang dan jasa yang beredar di masyarakat.

d) Menghemat devisa negara, terutama untuk produk-produk yang sebelumnya diimpor dan apabila sudah dapat diproduksi di dalam negeri dengan fasilitas kredit yang ada jelas akan dapat menghemat devisa negara.

e) Meningkatkan devisa negara, apabila produk dari kredit yang dibiayai untuk keperluan ekspor. 
Jumlah kredit yang disalurkan oleh bank kepada masyarakat menurut Sudirman (2013: 44) merupakan salah satu bentuk penggunaan dana bank yang menghasilkan pendapatan bank berupa bunga kredit. Jumlah kredit yang disalurkan oleh sebuah bank kepada masyarakat bersumber dari dana bank bersangkutan.

Selanjutnya Sudirman (2013: 75) mengemukakan bahwa dana bank dapat dibedakan menurut sumber dan cara penghimpunannya. Dana bank menurut sumbernya dibedakan menjadi:

1) Dana bank yang bersumber dari luar bank atau dari masyarakat disebut juga dana pihak ketiga atau DPK berbentuk giro, tabungan, deposito, dan pinjaman, serta bentuk lain yang dipersamakan dengan itu. DPK merupakan utang bagi bank sehingga pada saatnya dana tersebut akan ditarik oleh masyarakat. Yang dimaksud dengan masyarakat adalah perorangan, kelompok dan lembaga atau badan hukum tertentu. Yang dimaksud dengan lembaga adalah lembaga keuangan bank dan lembaga keuangan bukan bank.

2) Dana bank yang bersumber dari dalam bank disebut dana sendiri berupa modal yang disetor oleh pemilik bank atau oleh pemegang saham bank, laba ditahan, laba berjalan dan cadangan. Modal yang disetor oleh pemilik bank atau pemegang saham bank adalah sejumlah uang tunai yang dimiliki oleh pemilik bank atau pemegang saham bank yang bersumber dari bukan pinjaman yang disetor tunai di bank sebagai tambahan modal dan dinotariilkan. Laba ditahan adalah laba bersih bank setelah dikurangi pajak. Laba berjalan adalah laba bank sebelum tutup buku pada akhir tahun takwim yaitu 31 Desember. Cadangan adalah bagian dari laba ditahan yang diperuntukkan sebagai cadangan umum maupun sebagai cadangan khusus.

Jumlah DPK yang dihimpun oleh bank merupakan salah satu ukuran keberhasilan bank menurut fungsinya sebagai penghimpun dana masyarakat. Bank memiliki keleluasaan untuk menghimpun dana dari masyarakat, sehingga bank memiliki kemampuan yang tinggi dalam menyalurkan kredit kepada masyarakat. Kemampuan yang tinggi dalam menyalurkan kredit kepada masyarakat ini sebanding lurus dengan banyaknya jumlah kredit yang bisa ditawarkan oleh bank.

Kegiatan penyaluran kredit ini tidak lepas dari masalah risiko penyaluran kredit. Salah satu risiko yang ada adalah risiko kolektibilitas kredit. Menurut Sudirman (2013: 204) risiko kolektibilitas kredit merupakan kondisi tidak terkumpulnya kembali jumlah kredit bank yang disalurkan karena dalam kondisi angsuran atau pelunasan yang nonlancar atau dalam nonperforming loan yang sering disingkat NPL. NPL terdiri dari kredit dalam kondisi kurang lancar, diragukan atau macet. Semakin banyak kredit dalam kolektibilitas NPL akan semakin besar risiko yang akan terjadi, atau sebaliknya. Selanjutnya Sudirman (2013: 192) menjelaskan, dengan adanya risiko kredit berarti bank mengalami kegagalan dalam menyalurkan kredit. Kegagalan itu disebabkan oleh lemahnya manajemen kredit di samping adanya kelemahan di pihak nasabah seperti gagalnya usaha nasabah, perubahan karakter nasabah dan sebab lain seperti persaingan antarbank sehingga terbatasnya nasabah-nasabah yang layak diberikan kredit. Kondisi tersebut sering disebut bank berada dalam perubahan lingkungan.

Dampak lain dari risiko kredit menurut Sudirman (2013: 192) adalah mengurangi kemampuan bank dalam memenuhi kewajibannya atau berdampak pada risiko likuiditas. Risiko likuiditas menurut Sudirman (2013: 184) adalah risiko ketidakmampuan sebuah bank dalam memenuhi atau membayar kewajiban keuangannya tepat waktu seperti membayar tabungan pada saat ditarik oleh nasabahnya atau membayar deposito pada saat jatuh tempo dan kewajiban lainnya. Jika tidak mampu membayar tepat waktu, mungkin bank mampu membayar di kemudian hari dengan mencari pinjaman terlebih dahulu atau dengan cara lain. Walaupun demikian, tetap saja bank tersebut terkena risiko lain, yaitu risiko hilangnya kepercayaan masyarakat dan kemudian terkena risiko membayar bunga jika bank mencari pinjaman atau terkena risiko penurunan nilai aktiva bank jika bank menjual kekayaannya dengan harga murah 
demi untuk mendapatkan uang. Risiko kehilangan kepercayaan masyarakat akan berdampak terjadinya penarikan besar-besaran atas simpanan masyarakat pada bank atau disebut rush.

JURNAL

MANAJEMEN

INDONESIA

Vol. 12 - No. 4

April 2013
Akibat penarikan besar-besaran atas simpanan masyarakat pada bank, menyebabkan penurunan kemampuan bank dalam menyalurkan pinjaman pada masyarakat, sehingga keuntungan bank menjadi menurun atau bahkan menderita rugi.

Risiko likuiditas menurut Rivai (2013: 576) dapat dikategorikan sebagai berikut.

1) Risiko likuiditas pasar, yaitu risiko yang timbul karena bank tidak mampu melakukan offsetting posisi tertentu dengan harga pasar karena kondisi likuiditas pasar yang tidak memadai atau terjadi gangguan di pasar (market disruption).

2) Risiko likuiditas pendanaan, yaitu risiko yang timbul karena bank tidak mampu mencairkan asetnya atau memperoleh pendanaan dari sumber dana lain.

Risiko likuiditas dapat melekat pada aktivitas fungsional perkreditan (penyediaan dana), treasury dan investasi, kegiatan pendanaan dan instrumen utang.

Salah satu penilaian pendekatan kuantitatif terhadap faktor likuiditas menurut Rivai (2013: 483) adalah dengan melakukan perhitungan Loan to Deposit Ratio atau yang biasa disingkat menjadi LDR. Rasio ini adalah rasio yang mengukur perbandingan jumlah kredit yang diberikan bank dengan dana yang diterima oleh bank, yang menggambarkan kemampuan bank dalam membayar kembali penarikan dana oleh deposan dengan mengandalkan kredit yang diberikan sebagai sumber likuiditasnya. Artinya seberapa jauh pemberian kredit kepada nasabah kredit dapat mengimbangi kewajiban bank untuk segera memenuhi permintaan deposan yang ingin menarik kembali uangnya yang telah digunakan oleh bank untuk memberikan kredit. Maka, semakin tinggi rasio LDR, memberikan indikasi rendahnya kemampuan likuiditas bank tersebut. Oleh karena itu, semakin tinggi rasionya memberikan indikasi rendahnya kemampuan likuiditas bank tersebut.

Dampak lebih lanjut dari risiko kredit menurut Sudirman (2013: 192) adalah risiko kerugian di mana bank tidak menerima bunga dari kredit yang disalurkannya kepada masyarakat di balik bank membayar bunga dana dan biaya lainnya. Bunga kredit bank menurut Sudirman (2013: 173) adalah suku bunga uang yang diterima oleh bank dari penerima pinjaman atau debitur. Secara umum, besarnya suku bunga kredit ditentukan oleh pasar yaitu kekuatan antara pemberi dan penerima kredit. Penentuan tingkat suku bunga kredit dipengaruhi oleh beberapa faktor, yaitu:

1) Biaya dana bank atau cost of fund

Biaya dana merupakan dasar dalam penentuan suku bunga kredit di samping juga sebagai dasar dalam penentuan investasi dan penempatan dana yang dilakukan oleh bank sehingga bank tetap likuid, solvabel dan profit. Biaya dana diukur dengan suku bunga dana. Jika suku bunga sejumlah dana tinggi, suku bunga kredit juga akan tinggi atau sebaliknya. Biaya dana atau suku bunga dana dipengaruhi oleh struktur dari sumber dana di bank, misalnya giro, tabungan dan deposito.

2) Biaya operasi bank atau bank overhead cost

Dalam operasional sebuah bank, bank mengeluarkan biaya dengan jumlah tertentu, seperti biaya tenaga kerja, sewa kantor, biaya penyusutan, biaya transport, biaya promosi dan biaya lainnya. Semua biaya yang dikeluarkan oleh bank dibiayai dari pendapatan bank, yaitu salah satu pendapatannya berasal dari bunga kredit. Biaya operasional sebuah bank juga memengaruhi suku bunga kredit. Jika biaya operasional sebuah bank adalah tinggi, maka suku bunga kredit juga akan tinggi atau sebaliknya.

3) Risiko biaya atau risk cost

Risiko biaya yang mungkin terjadi selama operasional bank juga memengaruhi suku bunga kredit karena risiko tersebut harus dibiayai dari pendapatan bank, yang salah satunya berupa pendapatan dari bunga kredit, sehingga risiko biaya akan memengaruhi suku bunga kredit. Jika risiko biaya itu rendah, kemungkinan suku bunga kredit juga rendah atau sebaliknya. 
Keuntungan yang diinginkan oleh sebuah bank akan memengaruhi suku bunga kredit. Jika bank menginginkan untung yang lebih besar, suku bunga kredit akan lebih tinggi atau sebaliknya.

5) Pajak

Pajak atas bunga dana yang diterima oleh penyimpan dana juga memengaruhi suku bunga dana sehingga memengaruhi suku bunga kredit terutama kalau suku bunga dana ditanggung oleh bank, maka suku bunga kredit akan tinggi atau sebaliknya.

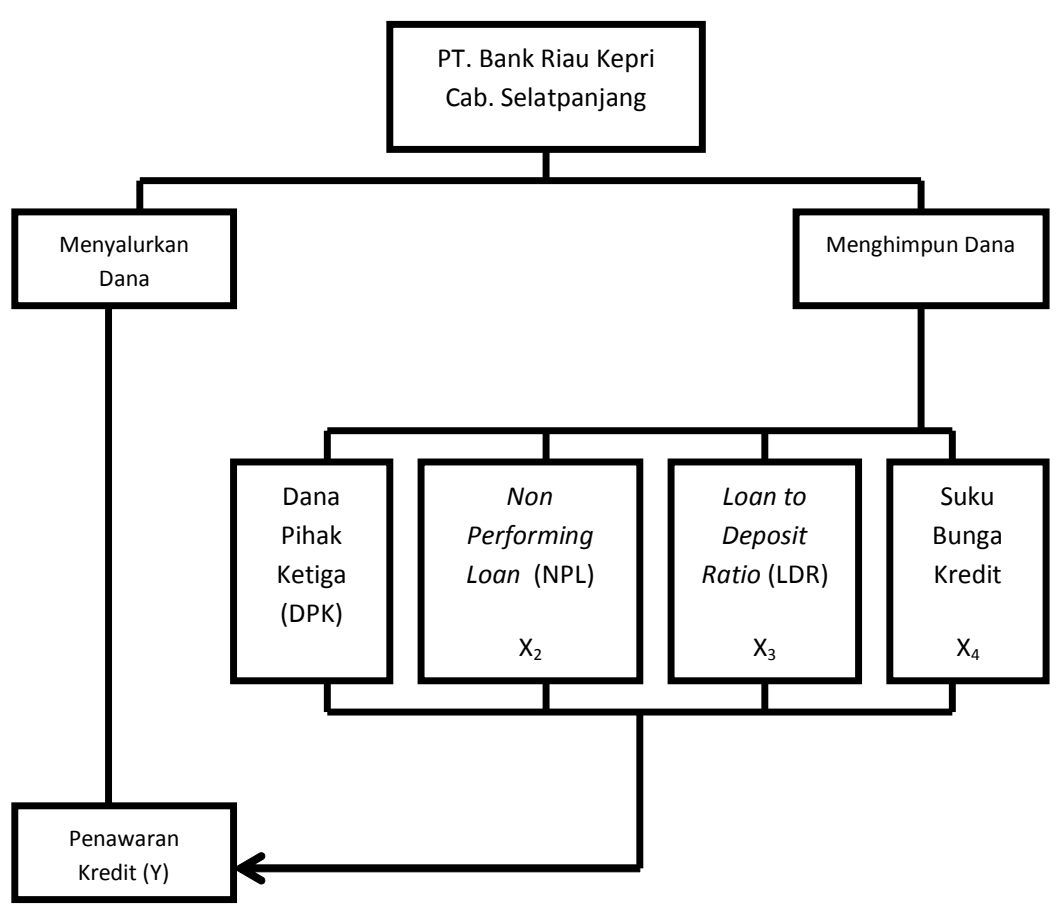

\section{METODE PENELITIAN}

Dalam penelitian ini, studi deskriptif dilakukan untuk menjawab tujuan penelitian poin pertama, yaitu Untuk mengetahui perkembangan Dana Pihak Ketiga (DPK), Non Performing Loan (NPL), Loan to Deposit Ratio (LDR), Suku Bunga Kredit dan Penawaran Kredit PT Bank Riau Kepri Cabang Selatpanjang dari tahun 2007 sampai dengan tahun 2012. Sekaran (2006:160) menerangkan bahwa studi deskriptif menampilkan data dalam bentuk yang bermakna, dengan demikian membantu untuk: (i) memahami karakteristik sebuah kelompok dalam situasi tertentu; (ii) memikirkan secara sistematis mengenai berbagai aspek dalam situasi tertentu; (iii) memberikan gagasan untuk penyelidikan dan penelitian lanjut; dan (iv) membuat keputusan tertentu yang sederhana.

Sedangkan studi verifikatif dilakukan untuk menjawab tujuan penelitian poin kedua dan ketiga, yaitu untuk mengetahui signifikansi pengaruh Dana Pihak Ketiga (DPK), Non Performing Loan (NPL), Loan to Deposit Ratio (LDR) dan Suku Bunga Kredit secara simultan maupun secara parsial terhadap penawaran kredit. Menurut Sekaran (2006:158) penelitian verifikatif adalah penelitian yang bertujuan untuk mengetahui pengaruh antar variabel melalui suatu pengujian hipotesis. 
JURNAL

MANAJEMEN INDONESIA

Vol. 12 - No. 4

April 2013

\begin{tabular}{|c|c|c|c|}
\hline Variabel & Konsep Variabel & Indikator & Skala \\
\hline $\operatorname{DPK}\left(\mathrm{X}_{1}\right)$ & $\begin{array}{l}\text { Dana pihak ketiga } \\
\text { merupakan sumber } \\
\text { dana bank yang } \\
\text { berasal dari } \\
\text { masyarakat sebagai } \\
\text { nasabah dalam } \\
\text { bentuk simpanan } \\
\text { giro, tabungan dan } \\
\text { deposito. }\end{array}$ & $\begin{array}{l}\text { Dana Pihak Ketiga }= \\
\text { giro + tabungan }+ \text { deposito }\end{array}$ & Rasio \\
\hline $\operatorname{NPL}\left(X_{2}\right)$ & $\begin{array}{l}\text { Non performing } \\
\text { loan atau sering- } \\
\text { disebut kredit } \\
\text { bermasalah dapat } \\
\text { diartikan sebagai } \\
\text { pinjaman yang } \\
\text { mengalamikesulitan } \\
\text { pelunasan akibat } \\
\text { adanya faktor kes- } \\
\text { engajaan dan atau } \\
\text { karena faktorekster- } \\
\text { nal di luar kemam- } \\
\text { puan kendali debi- } \\
\text { tur seperti kondisi } \\
\text { ekonomi yangburuk. }\end{array}$ & $N P L=\frac{\text { Jumlah Kredit Bermasalah }}{\text { Total Kredit disalurkan }} \times 100 \%$ & Rasio \\
\hline $\operatorname{LDR}\left(X_{3}\right)$ & $\begin{array}{l}\text { Loan to Deposit } \\
\text { Ratio (LDR) adalah- } \\
\text { rasio antara seluruh } \\
\text { jumlah kredit yang } \\
\text { diberikan bank } \\
\text { dengan dana yang } \\
\text { diterimaoleh bank. }\end{array}$ & $L D R=\frac{\text { Jumlah Kredit yang disalurkan }}{\text { Total Dana Pihak Ketiga }} \times 100 \%$ & Rasio \\
\hline $\begin{array}{l}\text { Suku Bunga } \\
\text { Kredit }\left(\mathrm{X}_{4}\right)\end{array}$ & $\begin{array}{l}\text { Suku bunga kredit } \\
\text { merupakan be- } \\
\text { sarnya tingkat bun- } \\
\text { ga yang dibebank- } \\
\text { ankepada nasabah } \\
\text { yang mendapat } \\
\text { fasilitas kredit dari } \\
\text { bank. }\end{array}$ & $\begin{array}{l}\text { Besarnya tingkat bunga yang dibebankankepada } \\
\text { nasabah yang mendapat fasilitas kredit dari bank. }\end{array}$ & Rasio \\
\hline $\begin{array}{l}\text { Penawaran } \\
\text { Kredit }(Y)\end{array}$ & $\begin{array}{l}\text { Kredit merupakan } \\
\text { penyediaan uang } \\
\text { atau tagihan yang } \\
\text { dapat dipersamakan } \\
\text { dengan itu, } \\
\text { berdasarkan } \\
\text { persetujuan atau } \\
\text { kesepakatan } \\
\text { pinjam-meminjam } \\
\text { antara bank dengan } \\
\text { pihak lain yang } \\
\text { mewajibkan pihak } \\
\text { peminjam untuk } \\
\text { melunasi utangnya } \\
\text { setelah jangka } \\
\text { waktu tertentu } \\
\text { dengan bunga. }\end{array}$ & $\begin{array}{l}\text { Jumlah kredit perbankan pada periode akhir } \\
\text { tahunan. }\end{array}$ & Rasio \\
\hline
\end{tabular}


Populasi dalam penelitian adalah laporan keuangan triwulanan PT. Bank Riau Kepri yang memiliki 19 cabang. Pemilihan sampel ini dipilih secara purpossive sampling dengan karakteristik sebagai berikut :

JURNAL

MANAJEMEN INDONESIA

a. Tidak menjadikan semua anggotanya sebagai sampel melainkan pemilihannya dilihat dari peningkatan laba yang signifikan dari tahun 2007 sampai dengan tahun 2012.

b. Dipilihnya PT. Bank Riau Kepri Cab. Selatpanjang dengan pertimbanganpertumbuhan ekonomi daerah Kabupaten Kepulauan Meranti yang beribukota Selatpanjang mengalami peningkatan yang signifikan melebihi pertumbuhan ekonomi nasional.

\section{Uji Asumsi Klasik Regresi}

Uji asumsi klasik regresi menurut Prayitno (2013: 49) merupakan uji prasyarat menggunakan analisis regresi linier. Uji ini antara lain uji normalitas residual, uji multikolinearitas, uji heteroskedastisitas, dan uji autokorelasi. Jika asumsi tersebut dilanggar, misal model regresi tidak normal, terjadi multikolinearitas, terjadi heteroskedastisitas, atau terjadi autokorelasi. Maka hasil analisis regresi dan pengujian seperti uji t dan $\mathrm{F}$ menjadi tidak valid atau bias.

\section{Analisis Regresi Linier Berganda}

Dalam penelitian ini, data yang telah dikumpulkan dianalisis dengan menggunakan analisis regresi berganda. Analisis regresi linier berganda menurut Prayitno (2013: 116) digunakan untuk mengetahui pengaruh antara dua atau lebih variabel independen dengan satu variabel dependen. Analisis ini juga untuk memprediksikan nilai dari variabel dependen apabila nilai variabel independen mengalami kenaikan atau penurunan, dan untuk mengetahui arah hubungan antara variabel independen dengan variabel dependen apakah masing-masing variabel independen berhubungan positif atau negatif. Variabel independen yang dimasukkan ada empat dengan satu variabel dependen. Persamaan regresi yang dibentuk adalah sebagai berikut:

$$
Y=a+b_{1} X_{1}+b_{2} X_{2}+b_{3} X_{3}+b_{4} X_{4}
$$

Keterangan:

$\mathrm{Y} \quad=$ Variabel dependen yang diprediksikan (penawaran kredit)

$\mathrm{X}_{1}, \mathrm{X}_{2}, \mathrm{X}_{3}, \mathrm{X}_{4}=$ Variabel independen (DPK, NPL, LDR dan Suku Bunga Kredit)

a = Nilai konstanta

$b_{1}, b_{2}, b_{3}, b_{4} \quad=$ Koefisien regresi

\section{a. Pengujian Hipotesis secara Simultan}

Prayitno (2013: 122) mengatakan bahwa uji F digunakan untuk menguji apakah variabel independen secara simultan berpengaruh terhadap variabel dependen. Hipotesis yang dirumuskan sebagai berikut:

$H_{0} \quad$ : Tidak terdapat pengaruh yang signifikan secara simultan antara DPK, NPL, LDR dan suku bunga kredit terhadap penawaran kredit pada PT. Bank Riau Kepri Cab. Selatpanjang.

$\mathrm{H}_{1}$ : Terdapat pengaruh yang signifikan secara simultan antara DPK, NPL, LDR dan suku bunga kredit terhadap penawaran kredit pada PT. Bank Riau Kepri Cab. Selatpanjang.

Kriteria pengujian dalam uji $F$ adalah:

- $\mathrm{H}_{\mathrm{o}}$ diterima bila $\mathrm{F}$ hitung $\leq \mathrm{F}$ tabel.

- $H_{0}$ ditolak bila $F$ hitung $>\mathrm{F}$ tabel. 
b. Pengujian Hipotesis secara Parsial

JURNAL

MANAJEMEN INDONESIA

Vol. 12 - No. 4 April 2013
Prayitno (2013: 120) mengatakan bahwa uji t digunakan untuk mengetahui apakah variabel independen secara parsial berpengaruh terhadap variabel dependen. Hipotesis yang akan dirumuskan sebagai berikut:

1) Pengaruh Dana Pihak Ketiga (DPK) terhadap Penawaran Kredit

$\mathrm{H}_{\text {oa }} \quad$ : DPK tidak berpengaruh secara signifikan terhadap penawaran kredit pada PT. Bank Riau Kepri Cab. Selatpanjang.

$\mathrm{H}_{1 \mathrm{a}} \quad$ : DPK berpengaruh secara signifikan terhadap penawaran kredit pada PT. Bank Riau Kepri Cab. Selatpanjang.

2) Pengaruh Non Performing Loan (NPL) terhadap Penawaran Kredit

$\mathrm{H}_{\mathrm{ob}} \quad$ : NPL tidak berpengaruh secara signifikan terhadap penawaran kredit pada PT. Bank Riau Kepri Cab. Selatpanjang.

$\mathrm{H}_{1 \mathrm{~b}}$ : NPL berpengaruh secara signifikan terhadap penawaran kredit pada PT. Bank Riau Kepri Cab. Selatpanjang.

3) Pengaruh Loan to Deposit Ratio (LDR) terhadap Penawaran Kredit

$\mathrm{H}_{\text {oc }} \quad$ : LDR tidak berpengaruh secara signifikan terhadap penawaran kredit pada PT. Bank Riau Kepri Cab. Selatpanjang.

$\mathrm{H}_{1 \mathrm{c}} \quad$ : LDR berpengaruh secara signifikan terhadap penawaran kredit pada PT. Bank Riau Kepri Cab. Selatpanjang.

4) Pengaruh Suku Bunga Kredit terhadap Penawaran Kredit

$\mathrm{H}_{\text {od }} \quad$ : Suku Bunga Kredit tidak berpengaruh secara signifikan terhadap penawaran kredit pada PT. Bank Riau Kepri Cab. Selatpanjang.

$\mathrm{H}_{1 \mathrm{~d}} \quad$ : Suku Bunga Kredit berpengaruh secara signifikan terhadap penawaran kredit pada PT. Bank Riau Kepri Cab. Selatpanjang.

Kriteria pengujian dalam uji t adalah:

- Ho diterima jika $-\mathrm{t}$ tabel $\leq \mathrm{t}$ hitung $\leq \mathrm{t}$ tabel.

- Ho ditolak jika -t hitung < -t tabel atau t hitung $>$ t tabel.

\section{c. Analisis Koefisien Determinasi(Adjusted $\mathrm{R}^{2}$ )}

Analisis determinasi digunakan untuk mengetahui persentase sumbangan pengaruh variabel independen secara bersama-sama terhadap variabel dependen. Uji $R^{2}$ pada intinya mengukur seberapa jauh kemampuan model dalam menerangkanvariasi variabel dependen. Nilai koefisien determinasi adalah antara nol dan satu.

\section{HASIL DAN PEMBAHASAN}

Berdasarkan hasil statistik, diketahui bahwa jumlah DPK tertinggi adalah sebesar Rp. 263,556,640,-, sedangkan jumlah DPK terendah adalah sebesar Rp. 11,455,278,- dengan ratarata jumlah DPK sebesar Rp. 74,738,071,-. Artinya dalam setahun PT. Bank Riau Kepri Cab. Selatpanjang bisa menghimpun dana rata-rata sebesar Rp. 74,738,071,-- Rasio NPL tertinggi selama periode penelitian 1.15 persen, sedangkan rasio NPL terendah mencapai 0.31 persen dengan rata-rata sebesar 0.7967 persen. Hal ini menunjukkan bahwa rasio NPL PT. Bank Riau Kepri Cab. Selatpanjang sejauh ini masih di bawah batas toleransi rasio NPL yang ditetapkan oleh Bank Indonesia (BI) yaitu 5 persen. Rasio LDR tertinggi sebesar 166.38 persen, sedangkan rasio LDR terendah mencapai 74.15 persen dengan rata-rata sebesar 119.7283 persen. Dengan ratarata nilai LDR sebesar 119.7283 persen, berarti likuiditas PT. Bank Riau Kepri Cab. Selatpanjang berada pada kategori tidak sehat karena rasio LDR lebih besar dari 115 persen berdasarkan kategori kesehatan bank menurut BI. Kemudian tingkat SBK tertinggi sebesar 9.99 persen, sedangkan SBK terendah mencapai 9.16 persen dengan rata-rata sebesar 9.6512 persen. Dan 
penawaran kredit paling tinggi adalah sebesar Rp. 205,345,777,- sedangkan penawaran kredit paling rendah adalah Rp. 12,691,475,- dengan rata-rata Rp. 65,768,021,-.

\section{Uji Asumsi Klasik Regresi}

Dari empat uji asumsi klasik yang dilakukan, terdapat masalah pada pengujian multikolinearitas. Nilai VIF variabel NPL dan LDR mendekati 10 diwaspadai sebagai gejala multikolinearitas. Untuk memastikan gejala multikolinearitas pada model ini maka dilakukan pengujian korelasi antar variabel independen menggunakan uji Korelasi Pearson. Dari hasil pengujian didapat nilai koefisien antara variabel NPL dan LDR memiliki nilai korelasi sebesar 0.930 . Nilai koefisien ini melebihi nilai absolut 0.8 sehingga dalam model ini terjadi multikolinearitas yang cukup serius. Maka harus dilakukan treatment khusus untuk mengatasi masalah multikolinearitas.

Hal pertama yang dilakukan adalah dengan melakukan transformasi logaritma natural. Namun setelah melakukan transformasi logaritma natural, ternyata tidak menghasilkan nilai VIF yang lebih kecil. Meskipun sudah ditransformasi, nilai VIF tetap di sekitar 9. Hal ini diduga karena variabel NPL dan LDR memiliki pola pergerakan yang sama namun bertolak belakang. Sehingga dapat disimpulkan bahwa dengan transformasi data tidak dapat mengatasi masalah multikolinearitas.

Cara kedua dilakukan dengan mereduksi variabel menggunakan nilai variabel yang telah ditransformasi menjadi logaritma natural. Variabel yang memiliki korelasi kuat yaitu NPL dan LDR akan direduksi secara bergantian untuk menentukan variabel mana yang tepat untuk dimasukkan ke dalam model. Berdasarkan perbandingan hasil yang didapat dari mereduksi variabel NPL dan LDR secara bergantian, maka penulis memilih model regresi pertama di mana variabel NPL yang direduksi. Keputusan ini diambil dengan mempertimbangkan berbagai aspek antara lain.

1) Pada model yang mereduksi variabel NPL didapat hasil bahwa DPK, LDR dan SBK berpengaruh signifikan secara parsial sesuai dengan teori yang ada.

2) Pada model yang mereduksi variabel NPL didapat hasil $R^{2}$ yang lebih besar dari model yang mereduksi variabel LDR.

\section{Analisis Regresi Linier Berganda}

Persamaan regresi ketiga variabel independen yaitu DPK, LDR dan SBK terhadap penawaran kredit adalah sebagai berikut.

Penawaran Kredit $(P K)=47.076+0.981(D P K)+41288760.1+0.008($ LDR $)-0.114(S B K)$

\section{Pengujian Hipotesis}

Dari hasil perhitungan didapat bahwa nilai F hitung sebesar 1963.052. Sementara itu nilai F tabel sebesar 3.098. Karena nilai $F$ hitung > F tabel atau $1963.052>3.098$, maka $\mathrm{H}_{0}$ ditolak. Artinya variabel bebas yang berupa DPK, LDR dan SBK secara simultan berpengaruh signifikan terhadap variabel terikat.

Sedangkan hasil dari perhitungan secara parsial dengan menggunakan uji t didapat hasil sebagai berikut.

\begin{tabular}{|c|c|c|c|c|c|}
\hline Variabel & t hitung & & t tabel & Keputusan & Pengaruh \\
\hline DPK & 68.291 & $>$ & 2.086 & Tolak $\mathrm{H}_{0}$ & Berpengaruh Signifikan \\
\hline LDR & 22.292 & $>$ & 2.086 & Tolak $\mathrm{H}_{0}$ & Berpengaruh Signifikan \\
\hline SBK & -2.645 & $<$ & -2.086 & Terima $\mathrm{H}_{0}$ & Berpengaruh Signifikan \\
\hline
\end{tabular}

JURNAL

MANAJEMEN INDONESIA

Vol. 12 - No. 4 April 2013
Tabel 2 Hasil Uji Statistik t 
Dari Tabel dapat dilihat bahwa nilai t tabel dengan df 20 yaitu $2.086(\mathrm{df}=24-3-1=20)$, dan taraf signifikan 0.05 maka dapat ditarik kesimpulan sebagai berikut:

JURNAL

MANAJEMEN

INDONESIA

Vol. 12 - No. 4

April 2013 a. Nilai t hitung variabel DPK lebih besar dari t tabel $(68.291>2.086)$, sehingga variabel DPK berpengaruh secara signifikan terhadap Penawaran Kredit.

b. Nilai t hitung variabel LDR lebih besar dari t tabel $(22.292>2.086)$, sehingga variabel LDR berpengaruh secara signifikan terhadap Penawaran Kredit.

c. Nilai t hitung variabel SBK berada di antara t tabel $(-2.645<-2.086)$, sehingga variabel SBK berpengaruh secara signifikan terhadap Penawaran Kredit.

\section{KESIMPULAN DAN SARAN}

\section{Kesimpulan}

1. Jumlah DPK tertinggi terjadi pada tahun 2012 di triwulan IV yaitu sebesar Rp. 263,556,640,, sedangkan jumlah DPK terendah terjadi pada tahun 2008 di triwulan I yaitu sebesar Rp. 11,455,278,-. Rasio NPL tertinggi selama periode penelitian 1.15 persen, sedangkan rasio NPL terendah mencapai 0.31 persen. Rasio LDR tertinggi sebesar 166.38 persen, sedangkan rasio LDR terendah mencapai 74.15 persen. Kemudian tingkat SBK tertinggi sebesar 9.99 persen, sedangkan SBK terendah mencapai 9.16 persen.

2. Pada penelitian ini terdapat masalah multikolinearitas. Hal ini ditandai dengan penemuan dua variabel yang berkorelasi tinggi yaitu variabel NPL dan LDR. Sehingga langkah yang diambil untuk mengatasi masalah ini adalah dengan mereduksi salah satu variabel. Dari hasil percobaan, diputuskan untuk mereduksi variabel NPL. Sehingga model regresi penelitian ini tidak mengikutsertakan variabel NPL.

3. DPK, LDR dan SBK secara simultan berpengaruh signifikan terhadap penawaran kredit sebesar 99.7 persen.

4. DPK, LDR dan SBK secara parsial berpengaruh signifikan terhadap penawaran kredit.

\section{Saran}

Adapun saran-saran yang dapat diberikan adalah sebagai berikut:

1. Bagi Pihak PT. Bank Riau Kepri Cab. Selatpanjang

Terkait dengan beberapa variabel yang terbukti berpengaruh signifikan bagi penawaran kredit, maka penulis memberikan beberapa saran sebagai berikut:

a. $\quad$ Agar Dana Pihak Ketiga (DPK) bisa terhimpun lebih banyak, maka PT. Bank Riau Kepri Cab. Selatpanjang hendaknya bisa meningkatkan kualitas pelayanan terhadap nasabah sehingga masyarakat menjadi senang dan tertarik untuk menabung di PT. Bank Riau Kepri Cab. Selatpanjang. Karena semakin banyak DPK yang dapat dihimpun, maka semakin banyak pula penawaran kredit yang bisa disalurkan oleh PT. Bank Riau Kepri Cab. Selatpanjang.

b. $\quad$ PT. Bank Riau Kepri Cab. Selatpanjang disarankan untuk menjaga rasio Loan to Deposit Ratio (LDR) agar tidak melebihi batas yang ditetapkan oleh BI yaitu 110 persen. Hal ini untuk menjaga kepercayaan masyarakat yang menabung di PT. Bank Riau Kepri Cab. Selatpanjang. Karena jika nilai rasio LDR lebih dari 110 persen berarti seluruh DPK yang terhimpun disalurkan dalam bentuk kredit oleh bank. Hal ini akan menimbulkan kekhawatiran akan kurangnya ketersediaan dana di pihak bank apabila sewaktu-waktu terjadi penarikan dana oleh deposan. Sehingga akan memberikan kesan kurang baik dari kacamata masyarakat.

2. Bagi Peneliti Selanjutnya

Bagi peneliti selanjutnya diharapkan dapat meneliti lebih lanjut dengan menggunakan variabel-variabel lain di luar variabel pada penelitian ini seperti Capital Adequacy Ratio (CAR). Menurut Rivai (2013 : 469 - 473), kewajiban modal minimum bank adalah berdasarkan risiko, termasuk risiko kredit. Untuk itu semua bank diwajibkan memenuhi 
tingkat kecukupan pemenuhan modal (Capital Adequacy Ratio-CAR) yang memadai untuk menjaga likuiditasnya. Bank tidak bisa semaunya mengucurkan kredit, apalagi terhadap institusi atau individu yang memiliki afiliasi dengan bank yang bersangkutan. Dengan kata lain, CAR adalah salah satu indikator kemampuan bank dalam menutup penurunan aktiva sebagai akibat kerugian yang diderita bank. Berdasarkan ketentuan Bank Indonesia, bank yang dinyatakan termasuk sebagai bank yang sehat harus memiliki CAR minimal 8 persen. Disarankan apabila ingin memasukkan variabel CAR hendaknya memilih objek penelitian bank yang bukan merupakan cabang dari suatu bank induk agar memperoleh data yang relevan.

Selain itu dapat pula menambahkan variabel kontrol berupa potensi daerah yang mendukung perkembangan penawaran kredit di suatu daerah tertentu. Hal ini dapat dilakukan agar memperoleh hasil yang lebih bervariatif yang dapat menggambarkan halhal lain yang dapat mempengaruhi penawaran kredit di luar faktor perhitungan kesehatan bank berdasarkan komponen-komponen CAMELS.

\section{DAFTAR PUSTAKA}

Anonim. (2013, 09 Januari). Meranti Butuh Pengusaha Muda [Online]. Tersedia: http:// haluankepri.com [diunduh pada 22 Maret 2013].

Anonim. (2013, 31 Januari). Pertumbuhan Ekonomi Meranti Meningkat. Haluan Kepri [Online]. Tersedia: http://haluankepri.com [diunduh pada 23 Maret 2013].

Anonim. (2013, 4 Februari). Bank Riau Siap Bantu Ekonomi Rakyat. Haluan Kepri [Online], Tersedia: http://haluankepri.com . [diunduh pada 23 Maret 2013].

Emeka, Ezike John. (2012). The Role and Sustainability of Microfinance Banks in Reducing Poverty and Development of Entrepreneurship in Urban and Rural Areas in Nigeria. International Journal of Business Administration. 3(3), 33-40.

Kasmir., (2009). Bank dan Lembaga Keuangan Lainnya, Jakarta: PT. Rajagrafindo Persada.

Mbugua, Mary Wanjiku. (2010). Impact of Microfinance Services on Financial Performance of Small and Micro Enterprises in Kenya. A Theses (MBA) in University of Nairobi, Kenya: tidak diterbitkan.

Mitra, Somjita. (2007). Macro Impact of Microcredit. A Dissertation Doctor of Philosophy Graduate Faculty of Economics in Claremont Graduate University California: tidak diterbitkan.

Priyatno, Duwi (2013). Mandiri Belajar Analisis Data dengan SPSS untuk Pemula, Yogyakarta: Mediakom.

Riggs, Thomas. (2008). Everyday Finance: Economics, Personal Money Management, and Entrepreneurship. Cengage Gale.

Rivai, Veithzal., et.al. (2013). Commercial Bank Management (Manajemen Perbankan dari Teori ke Praktik). Jakarta: PT. Rajagrafindo Persada.

Sarjono, Haryadi., \& Winda Julianita. (2011). SPSS vs LISREL: Sebuah Pengantar, Aplikasi untuk Riset. Jakarta: Salemba Empat.

Sekaran, Uma. (2006). Research Methods For Business; Metodologi Penelitian untuk Bisnis (edisi 4). Jakarta: Salemba Empat.

Sriram, Ven., \& Tigineh Mersha. (2010). Stimulating Entrepreneurship in Africa. World Journal of Enterprenuership, Management and Sustainable Development, 6(4), 257-272.

Sudirman, I Wayan. (2013). Manajemen Perbankan: Menuju Bankir Konvensional yang Profesional (edisi pertama). Jakarta : Kencana. 
Sugiarto, Agus. (2004). Mencari Struktur Perbankan Yang Ideal. Jurnal Bank Indonesia.

JURNAL Sugiyono. (2013). Metode Penelitian Bisnis. Bandung: Alfabeta.

MANAJEMEN

Sukirno, Sadono. (2006). Makroekonomi Teori Pengantar. Jakarta: PT RajaGrafindo Persada.

INDONESIA

Vol. 12 - No. 4

April 2013

Tambunan, Tulus. (2012). Usaha Mikro Kecil dan Menengah di Indonesia: Isu-isu Penting. Jakarta: LP3ES.

Wan Lee, Jung., \& Simon W.Tai. (2010). Motivators and Inhibitors of Entrepreneurship and Small Business Development in Kazakhstan. World Journal of Entrepreneurship, Management and Sustainable Development, Vol. 6, Nos. 1/2. 61-75. 